\title{
ポリエチレン単結晶マットの熱処理に伴う 微細構造変化と分散染料染着性の関係
}

\author{
山形大学工学部 米竹孝一郎 ・増子 徹 \\ 青砥浩一 - 真島正樹
}

\section{EQUILIBRIUM SORPTION OF DISPERSE DYE BY ANNEALED POLYETHYLENE SINGLE CRYSTAL MATS}

\author{
By Koichiro Yonetake, Toru Masuko, Koichi Aoto* \\ and Masaki Majima
}

(Faculty of Engineering, Yamagata University, Yonezawa-shi, Yamagata-ken, 992 Japan)

\begin{abstract}
Polyethylene (PE) single crystals prepared from $0.01 \mathrm{wt} \%$ solution of PE in xylene were sedimented to form mats. These mats were annealed at various temperatures ranging from $70 \sim 120^{\circ} \mathrm{C}$, and then were dyed at $80^{\circ} \mathrm{C}$ with C.I. Disperse Yellow 7 (Y-7) or p-aminoazobenzene. The equilibrium sorption $\left(M_{\mathrm{o}}\right)$, density, long period, and crystallinity $\left(C_{\mathrm{v}}\right)$ obtained for these single crystal mats increased with an increase in annealing temperature $\left(T_{\mathrm{a}}\right)$. These values increased rapidly over $T_{\mathrm{a}}=110^{\circ} \mathrm{C}\left(C_{\mathrm{v}}=0.858\right)$. The change in $M_{\mathrm{o}}$ was analyzed in terms of the mosaic-block dyeing model by use of above fine structural data. It was suggested that $M_{\mathrm{o}}$ was governed by the sorption in the amorphous side region $\left(M_{\mathbf{s}}\right)$ located between crystalline cores parallel to the molecular chain axis, and the sorption in the end amorphous region $\left(M_{\mathrm{e}}\right)$ located between lamellar surfaces was very small. From the view point of paracrystal model proposed by Hosemann, the amorphous side region corresponds to a grain boundary of microparacrystals. Hence, this region is rich in tie chains having trans type conformation. The difference between $M_{\mathrm{s}}$ and $M_{\mathrm{e}}$ is attributable to the fraction of tie molecules on which a long rod-like molecule, Y-7, is easily absorbed; few tie molecules exist in the end region of a single crystal mat. The conformation of tie chains in side region probably becomes more extended by the thickening of lamellae during annealing. This leads to the increase in $M_{\mathrm{o}}$ with increasing $C_{\mathrm{v}}$.
\end{abstract}

(Received February 5, 1985)

\section{1. 緒言}

結晶性高分子に対するモザイクブロック構造モデル (MB)は，最初Hosemann ら 单結晶内に存在するとして提案された。彼らは単結晶 メラ.内で分子銷がらせん転位などの格子不整を生じさせ るととによって，結晶が一辺約 $300 \AA$ のミクロパラクリ スタル(mPC)に分割されるとした。 Takayanagi ら

\footnotetext{
*現在の所属：ポリプラスチックス株式会社, 静岡県富 士市

Present Address: Polyplastics Co., Ltd., Fuji-shi, Shizuoka-ken, 416
}

は，とのMB構造モデルを利用して，PE 単結晶マット の動的粘弹性におりる結晶分散は $\mathrm{mPC}$ 間の境界領域内 で生じた分子銷のすべり变形に基つく現象之説明してい る。この考えは，延伸配向されたバルク試料の粘弾性変 化に対しても適用され，成果を収めた ${ }^{9)}$ 。

著者らは，MB構造を基として結晶性高分子に対する 分散染料の平衡染着量がラメラ晶の fold 部分 (amor phous end 領域)による吸着と, mPC間境界部分(amor phous side 領域)による吸着に分割される之仮定した。 この考えを熱処理 PEフィルム4)，熱処理ポリプロピ レン (PP)フィルム ${ }^{6}$, 溶剂処理 PP フィルム ${ }^{6)}$, 延 伸 PPフィルム 
いて，結晶化度の増加に伴う染着量增加現象は side 領 域による染着量增加に強く依存すると解䣋した。

本研究では，上記バルク試料よりも一層構造特性化を 行ない易いPE䍩結晶マットを用い，それによる分散染 料平衡吸着量に対しMB染着モデルが適用可能か否かを 調へて，結晶性高分子の染着性についての㫷礎的知見を 得ることを目的とする。著者らの知る限りに柿いては， 単結晶マットを染色した結果が報告された例は見当たら ない。

\section{2. 実銐}

\section{1 試 料}

高密度 PEペレット(チッソ株式会社製：M850)を用 いた。

重量平均分子量および分子量分布はそれぞれ $\bar{M}_{\mathrm{w}}=5.9$ $\times 10^{4}, \bar{M}_{\mathrm{w}} / \bar{M}_{\mathrm{n}}=5.0$ である。

\subsection{PE殚結晶マットの作製}

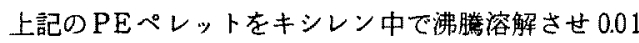
wt \%の濃度の希薄溶液を作製し，それを室温まで放冷し て単結晶析出させた。析出した単結晶のりん濁液をコ ック付きのガラスロートに入れコックを閉じたまま 24 時間静置した後,コックを徐々に開き单結晶が水平に皘 層するよう24時間かけてろ過した。得られた単結晶の ゲル状たい積物の上に研磨した賣ちゅう板を静加に乗 せ，その上に的 $500 \mathrm{~g}$ の重りを 1 個ずつ乗せてゆき合計 $1500 \mathrm{~g}\left(90 \mathrm{~g} / \mathrm{cm}^{2}\right)$ とした。との荷重をかけたまま 24 時間放置した後, 真品乾燥器中にて $50^{\circ} \mathrm{Cで} 24$ 時間乾燥 した。乾燥した単結晶マットをアセトン中で先浄し，真 空乾嬠器中にて 50 Cで恒量に達するまで乾燥した。以 上の方法により, 厚さ $150 \mu \mathrm{m}$, 直径 $4.5 \mathrm{~cm}$ の単結晶マ ットを得な。龟裂がなく，厚さむらの少ない( $(5 \mu \mathrm{m})$ 箁 所を選び供試料とした。

上記試料をアルミ䇴で包み，熱風循環式恒温槽に入れ， 所定温度 (70〜 $120 \mathrm{C}$ ) で空気中にて 24 時間熱処理した。

\section{3 電子影微鏡による観察}

\subsection{1 透過型電子顕洀鏡 (TEM) に上る観察} 日本電子製 JEM-200Aを使用し， $100 \mathrm{kV}$ の加速電 王にて検鏡および制限視野電子線回折を行なった。

\subsection{2 走查型電子顕媺鏡 (SEM) 亿⿺る観察} 日立製作所製 S-415 型走查型笔子顕微鏡を使用し， 加速電圧 $15 \mathrm{kV}$ 亿て単結晶マットの表面および断面を観 察した。断面の観察には，単結晶マットを液体窒菜中に 入れ十分冷却した後，液体窒素中で割った試料を用い to

\section{$2.4 P E$ 単結晶マットの染色}

染料はC. I. Disperse Yellow $7(\mathrm{Y}-7)\llcorner p$-Amino- azobenzene (PAAB)を水一エタノール(1:1)混合溶 媒および水から再結晶させて精製したものを用いた。を れぞれの染浴は，Y-7は $40 \mathrm{mg} ， P A A B は 250 \mathrm{mg}$ $2500 \mathrm{ml}$ の純水に非イオン系界面活性剂 Neugen $\mathrm{HC}$ (第 一工業製薬) $1 \mathrm{~g}$ と共に加えて， $80^{\circ} \mathrm{C}$ にて加温溶解させ るととにより調製した。上記の染浴に，種々の温度で熱 処理した単結晶マットを浸清し(浴比 $1: 10000$ )，80 8 にて平衡染着量に達するまで55 日間染色した。染色後， 試料を染浴より取り出し，純水およびメタノールで洗浄 してから乾燥した。それぞれの染色試料を $120^{\circ} \mathrm{C}$ の） クロルベンゼンに溶解し室温に戻した後，ガラスろ紙で ろ過しポリマーをろ別して得大染料溶液について，分光 光度計(島津UV240)を用いて比色定量するととにより 染着量を求的た。

\section{5 密度測定}

密度 $(\rho)$ は染色した試料について，水/nープロパノー ル系密度勾配管を用いて $25^{\circ} \mathrm{C}$ で測定した。

\subsection{X線回折}

理学電機社製 RAD-rA 型 X楾回折装置およひ位置敏 感形比例計数管 (PSPC) システムを使用した。 Niでろ 波した $\mathrm{CuK}_{\alpha}$ 線を用い， $50 \mathrm{kV}, 200 \mathrm{~mA}$ ○出力で測定し た。測定はいずれ娄染色した試料について行なった。

\subsection{1 広角 $X$ 線回折 (WAXD)}

広角 X線写真は平板カメラを用いて，カメラ半径 55.5 $\mathrm{cm}$ で撮影した。

又，広角 X線回折強度曲線より結晶散舌および非晶散 乱の積分強度を求め, Fischer $5^{8)}$ の式を用いてX線法 結晶化度 $\left(C_{\mathrm{x}}\right)$ を算出した。更に，体積結晶化度 $\left(C_{\mathrm{v}}\right)$ を $C_{\mathrm{v}}=\left(\rho / \rho_{\mathrm{c}}\right) C_{\mathrm{x}}$ の関係式より求めた $\left(\rho_{\mathrm{c}}\right.$ は結晶の密度 で $\rho_{\mathrm{c}}=0.9923 \mathrm{~g} / \mathrm{cm}^{3}$ を用いた $)^{8)}$ 。

凯結晶サイズと第 2 種の格子の乱れ度をHosemannWilke 方法 ${ }^{1,10)}$ により求加。( $\left.h k l\right)$ 面の回折強度分 布のプロフィルがガウス型と仮定すると，その広がりと 面閪隔の相対的ゆらざ間に次式の上うな関係が成立す る。

$$
\begin{aligned}
\left(\delta_{\mathrm{s}}\right)_{\mathrm{o}}^{2} & =\left(\delta_{\mathrm{s}}\right)_{\mathrm{c}}^{2}+\left(\delta_{\mathrm{s}}\right)_{\mathrm{II}}^{2} \\
& =1 / \bar{L}_{h k l}^{2}+\left(\pi \cdot g_{\mathrm{II}}\right)^{4} m^{4} / d_{h k l}^{2} \\
\left(\delta_{\mathrm{s}}\right)_{0} & =\beta \cos \theta / \lambda
\end{aligned}
$$

こてで $\left(\delta_{\mathrm{s}}\right)_{\mathrm{o}}$ は試料の $(h k l)$ 面に関する回折強度曲線 の積分幅であり，( $\left.\delta_{\mathrm{s}}\right)_{\mathrm{c}}$ はそのうちの結毘の大きさによ る広がりを表わし，( $\left(\delta_{\mathrm{s}}\right)_{\mathbb{I I}}$ は面間隔のゆらぎ(第2 種の 乱れ)による広がりを表わす。 $\bar{L}_{h k l}$ は $(h k l)$ 面に垂直な 方向の微結晶の広がり， $g_{\mathrm{II}}$ は第 2 種の乱れのパラメー 夕， $m$ は反射次数である。 $\beta$ は試料の回折強度曲線の積 分幅で，へキサメチレンテトラミンの反射の積分幅を用 いて装置による㕕がりを補正した值である。 
ここではPE単結晶マットについて(110), (200)，（330）面の回折強度曲線を測定し， Hosemann-Wilke プロット $\left[\left(\delta_{9}\right)_{0}-m^{4}\right]^{1,10)}$ を行ない，その直後の切片之傾きより(1) 式 をあちいて $\bar{L}_{h k l}$ と $g_{\text {II }}$ の値を算出した。

2.6.2 小角 $\mathrm{X}$ 線回折 (SAXS)

幅約 $1.5 \mathrm{~mm}$ の短冊形に切ったPE単結晶マ ット1枚にマットの膜面に平行にX線を入射

して測定した。

小角 X線写真は第 1 , 第 2 スリットとも 0.2 $\mathrm{mm}$ のピンホールスリットを使用し, カメラ 半径 $440 \mathrm{~mm}$ にて, $50 \mathrm{kV}, 200 \mathrm{~mA}$ の出力で 約 2 時間照射することにより撮影した。散乱 像の最大強度点間距離を測定し, 長周期 $\left(L_{\mathrm{p}}\right)$ を算出した。

小角 $\mathrm{X}$ 線散乱強度曲線は PSPCを用いて 測定した。第 1 ，第 2 スリットとも $0.2 \mathrm{~mm}$ の ピンホールスリットを用い, 有効長 $50 \mathrm{~mm}$ のプローブを使用し，50kV, $200 \mathrm{~mA}$ の出力 で60〜100 秒の計数時間で測定した。1 次の 散乱ピークの位置より $L_{\mathrm{p}}$ を求めた。

\section{3. 結果と考察}

3.1 PE単結晶およひ旄結晶マット の熱処理に伴う微細構造変化

本研究において得られた $\mathrm{PE}$ 単結晶は一辺 は約 $0.5 \mu \mathrm{m}$ であって，ほとんど同一サイズ であった。これらについて得られた電子線回 折像は鮮明で，斜方晶系の結晶構造を確認した。図 1 (a) はPE単結晶マットの断面のSEM写真である。ラメ ラが重なってマットの膜面に沿って積層している様子が 観察される。更に，ての断面に垂直にX線を入射して撮 影したWAXD (図 1 (b)) および SAXS 写真(図 1 (c)) より判断すると, WAXD像は繊維図形を示しており, C軸がマットの膜面に対しほぼ垂直に配向していること が認められ，また SAXS 像は 2 次反射まで観察される 層線状散乱を示すことより，ラメラは平均的に膜面にほ ぼ平行に積層していると推察される。

単結晶マットの密度は熱処理温度の上昇とともに単調 に増加する傾向が認められ，乙れらの值は $0.969 \sim 0.978$ の間にあり，これまでに他の研究者 ${ }^{8,11)}$ が測定した単結 晶マットの值にほぼ近い值が得られた。

図 2 に熱処理に伴う $C_{\mathrm{v}}$ 求よび $L_{\mathrm{p}}$ の変化をあわせて示 した。 $C_{\mathrm{v}}$ は熱処理温度にともなって増加し， $110^{\circ} \mathrm{C}$ 加 ら急激に増加する傾向がある。熱処理温度の上昇に伴い $L_{\mathrm{p}}$ も増加し，同様に $110^{\circ} \mathrm{C}$ 以上になると急激に増加す

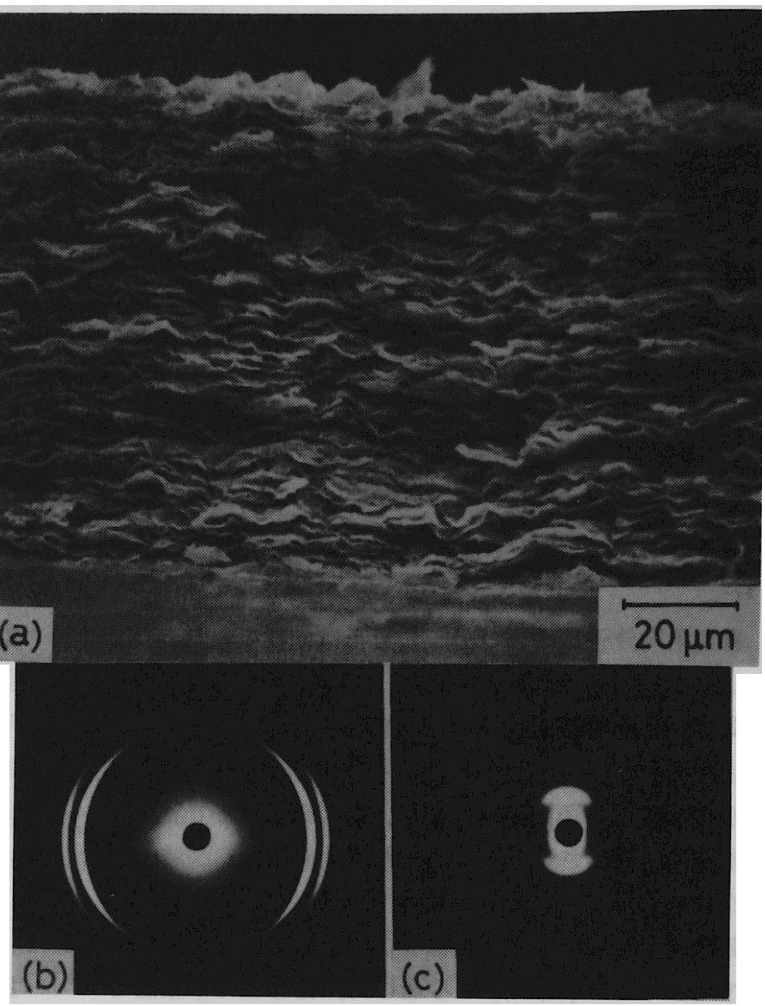

Fig. 1 (a) Scanning electron micrograph showing the edge of a PE single crystal mat; (b) WAXD pattern; (c) SAXS pattern. The directions of the incident $\mathrm{X}$-rays are parallel to the surface of the PE single crystal mat.

る。この $L_{\mathrm{p}}$ の増加傾向は Statton ら ${ }^{12)}$ および Fischer $ら^{18)}$ の結果とほぼ一致している。PE単結晶における熱 処理に伴う $L_{\mathbf{p}}$ の増加はラメラの厚化によると一般に解 釈されている。

図 3 には $C_{\mathrm{v}}$ に対する $L_{\mathrm{p}}$ と $\bar{L}_{110}$ の変化を示した。 $L_{\mathrm{p}}$ は初めはほとんど変化しないが $C_{\mathrm{v}}=0.858\left(T_{\mathrm{a}}=110^{\circ} \mathrm{C}\right)$ を超えると単調に増加する傾向が認められる。 $\bar{L}_{110}$ は $C_{\mathrm{v}}$ の増加に伴い初めからわずかに増加するが, $L_{\mathrm{p}}$ ほど 大きな変化は認められない。このような結果より, 熱処 理に伴う $C_{\mathrm{v}}$ の増加, 特に $C_{\mathrm{v}}=0.858$ 以上の増加は主に ラメラの厚化に因るものと推察される。

熱処理に伴う SAXS 強度曲線と SAXS 像の変化を図 4 亿示した。低い熱処理温度領域においては, SAXS 強 度曲線に 2 次および 3 次の散乱が認められるととからラ メラの子午線方向の周期性が良好であると判断できる。 この高次の散乱は熱処理温度の上昇とともにしだいに消 失し $115^{\circ} \mathrm{C}$ 以上の高温域ではほとんど認められない。こ のような結果より, 熱処理温度が高くなるとラメラの子 


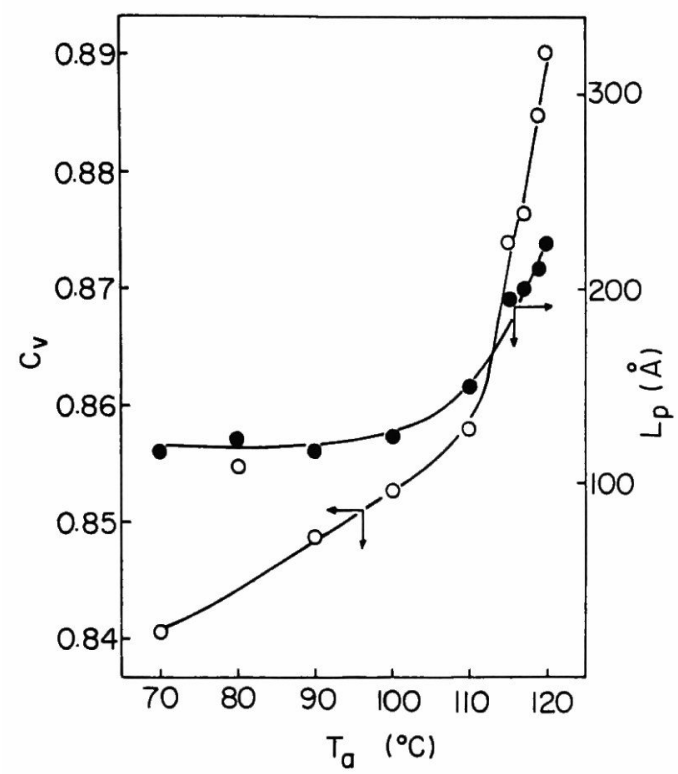

Fig. 2 Volume crystallinity $\left(C_{\mathrm{v}}\right)$ and long period $\left(L_{\mathrm{p}}\right)$ plotted against annealing temperatures. Open and closed circles denote $C_{\mathrm{v}}$ and $L_{\mathrm{p}}$, respectively.

午線方向の周期性が乱れてくるものと推定される。一方, SAXS写真において低温域では層状の散乱像を示すが, $110^{\circ} \mathrm{C}$ 以上になると散漫な点状散乱となり，115 $\mathrm{C}$ を越 すとしだいに明瞭な点状散乱に変化するようである。従 って, $90^{\circ} \mathrm{C}$ から $110^{\circ} \mathrm{C}$ までの間で微結晶は $C$ 軸に垂直方 向に生長するととが示嘫される。

図 5 に熱処理を行なった単結晶のTEM写真を示した。 $T_{\mathrm{a}}$ が低い領域では, edge のシャープなひし形の単結晶 が観察されるが, $T_{\mathbf{a}}=115$ C 付近より単結晶に細孔が観 察され，さらに $T_{\mathrm{a}}$ が高くなると細孔が全体に広がり， 1 個の孔も大きくなっている。とのような細孔が形成す るのは，ラメラが厚化する際に，周囲の分子銷を取り込 むためであると一般に考えられているが，本研究におい てもこのれのあく現象が認められる熱処理温度領域は， $L_{\mathrm{p}}$ の值が急激に增加する領域と一致しているととが確 認された。

以上の結果をもとに, 図6亿熱処理過程における $\mathrm{PE}$ 単結晶マットの微細構造変化を模式的に表わしてみた。 $T_{\mathrm{a}}=110^{\circ} \mathrm{C}$ までは, 結晶化度, 長周期, $C$ 軸㲹垂直方向 の微結晶の広がりにあまり大きな変化はなく, ラメラ積 層の子午線方向の周期性屯比較的保たれている。110 $115^{\circ} \mathrm{C}$ では, ラメラの厚化が起こり, 結晶化度が增加し 始め, ラメラ積層の子午線方向の周期性に乱れが現われ てくる。 $115^{\circ} \mathrm{C}$ 以上になるとラメラが急激に厚化し, 結

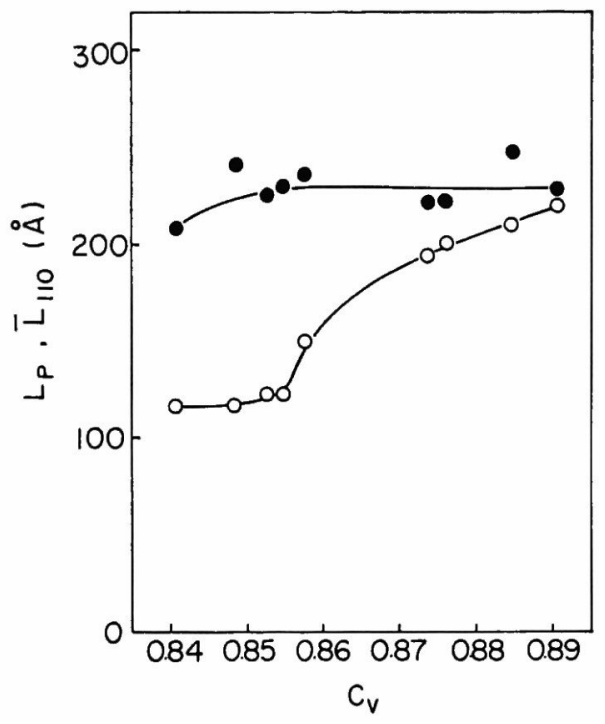

Fig. 3 Long period $\left(L_{\mathrm{p}}\right)$ and crystalline size $\left(\bar{L}_{110}\right)$ plotted against volume crystallinity. Open and closed circles denote $L_{\mathrm{p}}$ and $\bar{L}_{110}$, respectively.

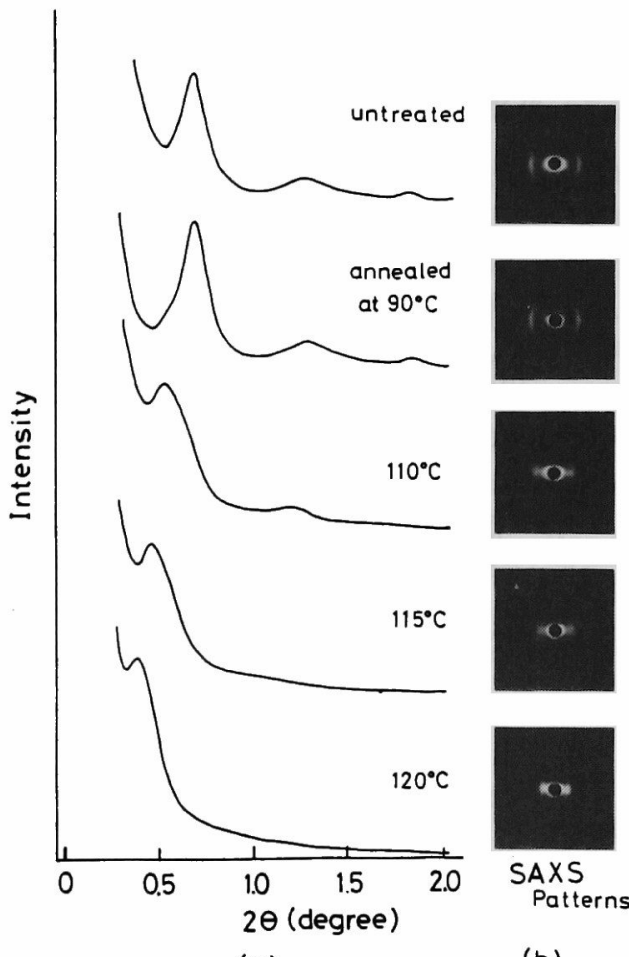

(a)

Fig. 4 The SAXS intensity curves and patterns for $P E$ single crystal mats annealed at various temperatures. 

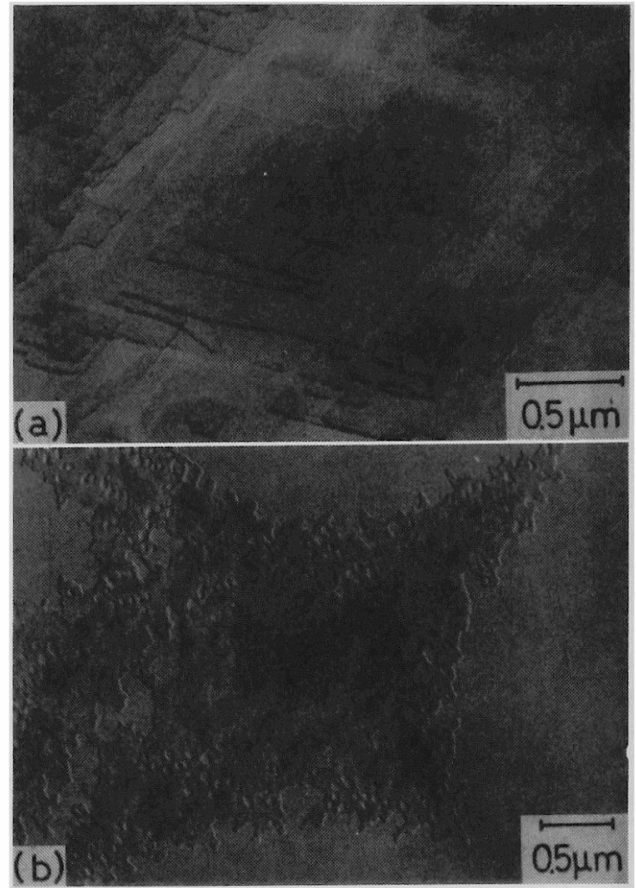

Fig. 5 Transmission electron micrographs for annealed PE single crystals: (a) annealed at $80^{\circ} \mathrm{C}$; (b) annealed at $119^{\circ} \mathrm{C}$.

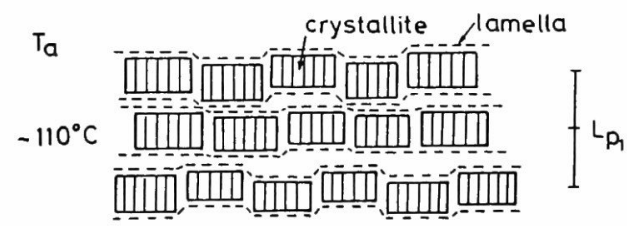

$110 \sim 115^{\circ} \mathrm{C}$

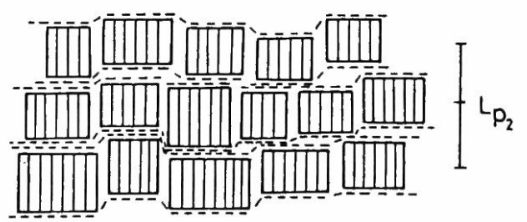

$115 \sim 120^{\circ} \mathrm{C}$

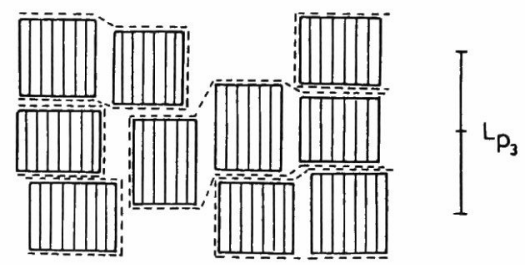

Fig. 6 The schematic representations of crystalline lamellae in the annealed PE single crystal mats.
晶化度む大きく増加する。更に, このラメラの厚化のた めに空孔が生じ, ラメラ積層の子午線方向の周期性が一 層乱れてくる。

\section{$3.2 P E$ 単結晶マットへの分散染料の染着}

図 7 に PE単結晶マットに対する分散染料 $(Y-7)$ の染 着速度曲線を示した。熱処理温度 $11^{\circ} \mathrm{C}$ と $119^{\circ} \mathrm{C}$ の試料 についての結果であるが，いずれも染色時間 50 日程度 で十分に平衡に達している。

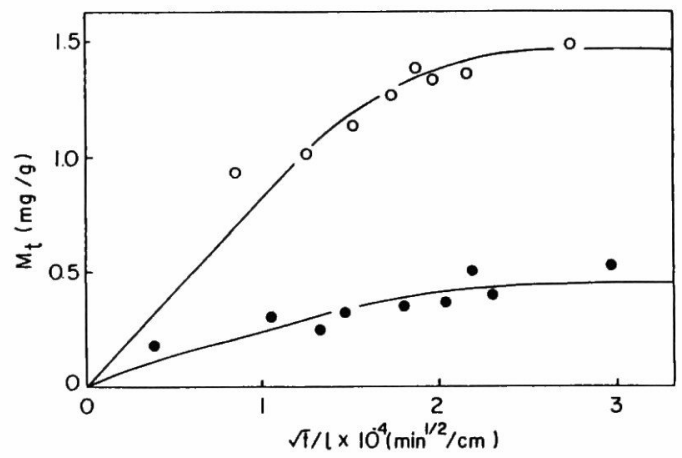

Fig. 7 Changes in dye uptakes $(\mathrm{Y}-7)$ at $80^{\circ} \mathrm{C}$ against the reduced time. Open and closed circles denote the PE single crystal mats annealed at $119^{\circ} \mathrm{C}$ and $110^{\circ} \mathrm{C}$, respectively.

種々の温度で熱処理したPE単結晶マットにおりる Y-7 と PAABの平衡染着量の変化を図 8 に示した。Y7, $\mathrm{PAAB}$ と屯 $110^{\circ} \mathrm{C}$ 超えると急激に増加する傾向を 示し, 特にY-7 の場合その増加は著しい。図中に点線 で示したのは熱処理 PEフィルム系" におりる結果であ る。フィルムの染着量は単結晶マットの 4 5 倍あるが, $\mathrm{Y}-7$ の場合 $120^{\circ} \mathrm{C}$ 付近になると単結晶マット $M_{\mathrm{o}}$ の值の 方が高くなるという結果が得られた。バルク試料に比へ れば, 単結晶マットは結晶化度が非常に高いので, 単結 晶マットの $M_{\mathrm{o}}$ はバルクフィルムの $M_{\mathrm{o}}$ より小さくなるあ のと考えられるが，単結晶マットにおける $120^{\circ} \mathrm{C}$ 付近の $M_{\mathrm{o}}$ の異常な增加現象より，染料吸着には単純な非晶の 量的な比較だけでは解決できない問題があることが示唆 される。

この $M_{\mathrm{o}}$ の変化を $C_{\mathrm{v}}$ に対してプロットしたのが図 9 で ある。 $C_{\mathrm{v}}$ の増加に伴い $M_{\mathrm{o}}$ は明らかに増加する傾向が認 められる。このような傾向はこれまでに著者らが熱処理 $\mathrm{PE} フ ィ ル ム$ 系 $^{4)}$ や熱処理 PPフィルム系 ${ }^{5)}$, 溶剂処理 $\mathrm{PP}$ フィルム系 ${ }^{6)}$ などバルクの系において得た結果と類 似している。特にPE 単結晶マットの場合には, 前項で 示した結晶化度および長周期が大きく変化する $T_{\mathrm{a}}=110$ ${ }^{\circ} \mathrm{C}\left(C_{\mathrm{v}}=0.858\right)$ 以上で $M_{\mathrm{o}}$ の值も急激に增加していると 


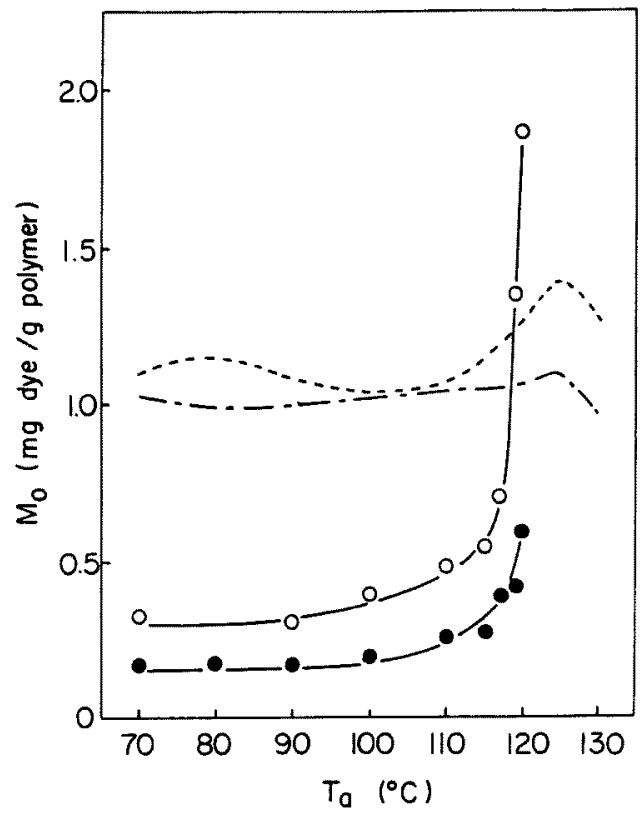

Fig. 8 Equilibrium dye uptakes of Y-7 and PAAB by $P E$ single crystal mats plotted against annealing temperatures.

The symbols indicated are as follows:

(O) for Y-7; (1) for PAAB.

The dotted (-.-) and broken (- - ) lines are the curves for equilibrium dye uptakes of Y-7 and PAAB by annealed PE films, respectively.

いうように微細構造团子の变化之明瞭な刘応があること 加ら，熱処理に伴う微細構造変化之平衡染着量の変化 の間には強い相関があると推定される。

Y-7の $M_{\circ}$ がPAABの $M_{0}$ に比較して大きいという傾 向は，バルクの系において得られた傾向" ${ }^{4}$ 之類似してい るが，その差はバルク試料においては低温領域で $10 \%$ 高温領域で $30 \%$ 程度であるのに対し，PE単結晶マット の場合には低温領域ですでに約 2 倍程度の違いがある。

\subsection{MB染着モデルによる解析}

MB 染着モデルについては前報"で詳しく述へててある が，いわゆるポリマー中の非晶領域を微結晶 core の底 面すなわち fold領域 (end 領域) と微結晶 core の側面の 非晶領域 (side 領域)の 2 種に分的両者の染着性につい て解析を行なう内容を持つ。この染色モデルでは，平衡 染着量 $M_{0}$ を side 領域に上る染着量 $\left(M_{0}\right)$ と end 領域に よる染着量 $\left(M_{e}\right)$ に分割し, 下記のように定義する。

$$
\begin{aligned}
M_{\mathrm{o}} & =M_{\mathrm{s}}+M_{\mathrm{e}} \\
& =\left(K_{\mathrm{s}} \cdot V_{\mathrm{s}} / V_{\mathrm{b}}+K_{\mathrm{e}} \cdot V_{\mathrm{e}} / V_{\mathrm{b}}\right) \cdot c / \rho
\end{aligned}
$$

ここで $V_{\mathrm{s}}, V_{\mathrm{e}}$ は side および end 領域の体積， $V_{\mathrm{b}}$ は

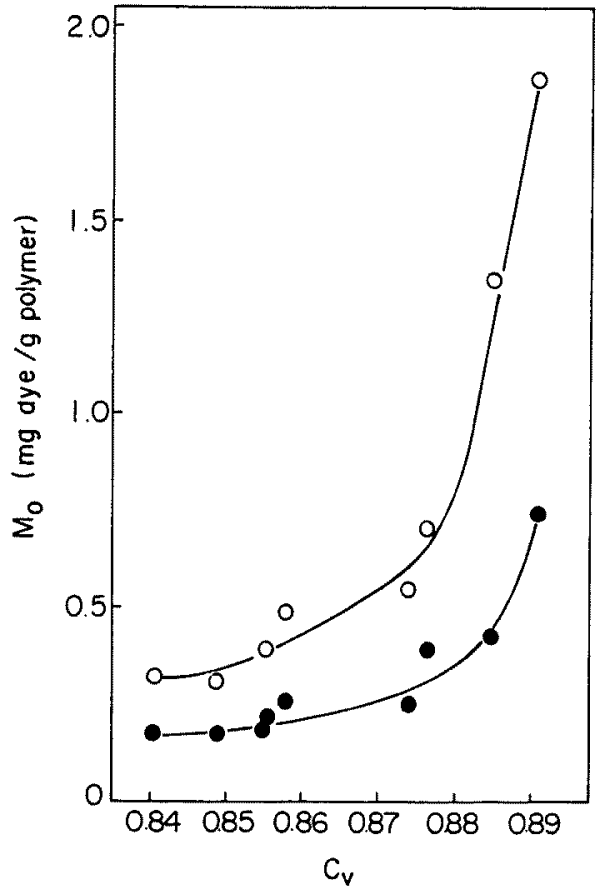

Fig. 9 Equilibrium dye uptakes of Y-7 and PAAB plotted against volume crystallinity.

The symbols are the same as those of Fig. 8 .

1 個のMBの体積， $K_{\mathrm{s}}, K_{\mathrm{e}}$ はそれぞれの領域の染着効率, cは染浴濃度である。(3)式は微細構造パラメータを用 いて次のように表わされる。

$$
\begin{aligned}
& M_{\mathrm{o}}= C_{\mathrm{v}}^{2} \cdot(2+p) p(1+p)^{2} L_{\mathrm{p}} \cdot m_{\mathrm{s}} \cdot c \\
&+\left[1-(1+p)^{2} C_{\mathrm{v}}\right] K_{\mathrm{e}} \cdot c \\
& p=h / l_{\mathrm{s}}
\end{aligned}
$$

ことで $m_{\mathrm{s}}$ は $K_{\mathrm{s}}=l_{\mathrm{c}} \cdot m_{\mathrm{s}}$ の式で定義される微細構造に依 存しない定数である。また，hは side領域の厚さであり， $l_{\mathrm{s}}$ はC 軸に垂直方向の微結晶 core のサイズである。本 研究で用いた $\mathrm{PE}$ 単結晶マットの場合には, $l_{\mathrm{s}} \cong \bar{L}_{110}$ 之 近似した。

更に，(4)式は次のように表わすことができる。

$$
\begin{aligned}
& \eta=\xi \cdot m_{\mathrm{s}} \cdot c+K_{\mathrm{e}} \cdot c \\
& \eta=M_{\mathrm{o}} \cdot \rho /\left(1-(1+p)^{2} C_{\mathrm{v}}\right] \\
& \xi=C_{\mathrm{v}}^{2}(2+p) p(1+p)^{2} L_{\mathrm{p}} /\left[1-(1+p)^{2} C_{\mathrm{v}}\right)
\end{aligned}
$$

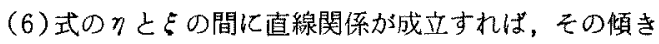
$m_{\mathrm{s}} \cdot c$ と切片 $K_{\mathrm{e}} \cdot c$ か得られ，それによって $M_{\mathrm{s}}$ と $M_{\mathrm{e}}$ 老 算出するととができる。

そこで前項に示した微練構造パラメー夕值を上式に代

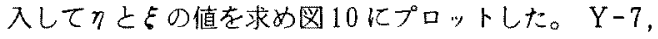
$\mathrm{PAAB}$ 系とあ $\eta-\boldsymbol{\xi}$ の間には良好な直線関係があり，従 ってPE筆結晶マット系伛いてもMB染着モデルの適 


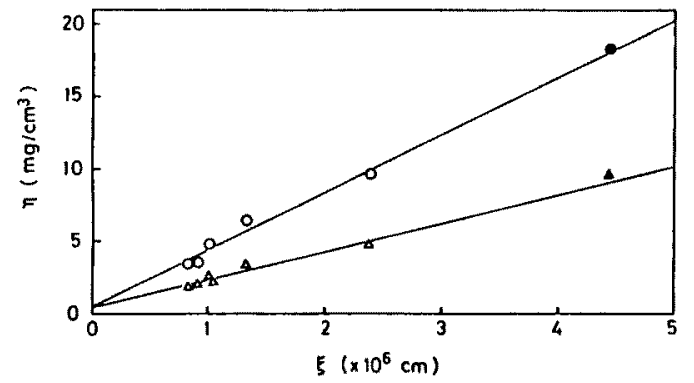

Fig. 10 Test plots based on Fig. (6). The line was drawn by the least square fitting to the data of each dyeing system. The marks indicated are as follows: (O) for $Y-7$ $(p=0.04) ;(\bullet)$ for Y-7 $(p=0.048) ;(\triangle)$ for $\mathrm{PAAB} \quad(p=0.04)$; ( $\Delta$ ) for PAAB $(p=0.048)$.

用が可能である。

ここで，(7)式で定義されるpの值は，バルク試料に おいて 0.1 と仮定してきだ〜7)。それに対して，本研究 で使用したPE単結晶マットにおいては 0.04 という值を 仮定した。その根樾は次のような考元に基ついている。 まず side 領域層厚 $h((7)$ 式)にY-7の上うな染料 (幅 約 $6 \AA ̊$ : ベンゼン環の幅汇相当 $)^{14)}$ が入り込みうる最低 のスペースを考䁍すると $h>6 \AA ̊ 丿$ となる。次に，MB染 着モデルに推いて， end 領域の厚さ $l_{\mathrm{a}}$ は $l_{\mathrm{a}}=L_{\mathrm{p}}(1-$ $(1+p)^{2} C_{\mathrm{v}}$ 了で表わされる。単結晶マットはバルク試料 とは異なりラメラ間には tie 分子は極めてわずかであり， ほとんどが fold 部分よりなっていると考えられる。従 って，単結晶マットのラメラ間非晶の厚さはバルクと比 へるとかなり小さいと推察される。この非晶層厚の最低 值として, fold の安定したコンホメーションと推定され ている regular sharp fold ${ }^{16)} の$ fold 部分の高さ(約 $2.5 \AA$ ) の倍に見積った值約 $5 \AA$ を考えると， $l_{\mathrm{a}}>5 \AA$ えとな る。このような条件に $C_{\mathrm{v}} ， L_{\mathrm{p}}$ 球よび $l_{\mathrm{g}}$ の実測值を入 れて検討すると， $p$ のとうる值の籍囲は $0.028<p<$ 0.055 之いう結果が得られた。本研究ではこの条件を満 たす值として上記推定值の中間の值である $p=0.04$ を採 用した。

それぞれの直線は図中の黒印のプロットを除いた全て のプロットを用いて，最小自乗法に上り求めた回㷌直絿 である。この黒印で示したプロットは $T_{\mathrm{a}}=117 \mathrm{C}$ の試料 であり， $p=0.048$ 上の值をわずかに変えることによっ て直線汇乗るようにした。しかし， $M_{0}$ が急激に増加す る結晶化度の高い試料については $p$ を記の範囲内で変 えても直線より著しくはずれた。

この直線の傾さと切片を求めて MB染着モデルの解析 飞従って， $M_{\mathrm{s}}$ と $M_{\mathrm{e}}$ を算出した。図11，12 亿 PAAB

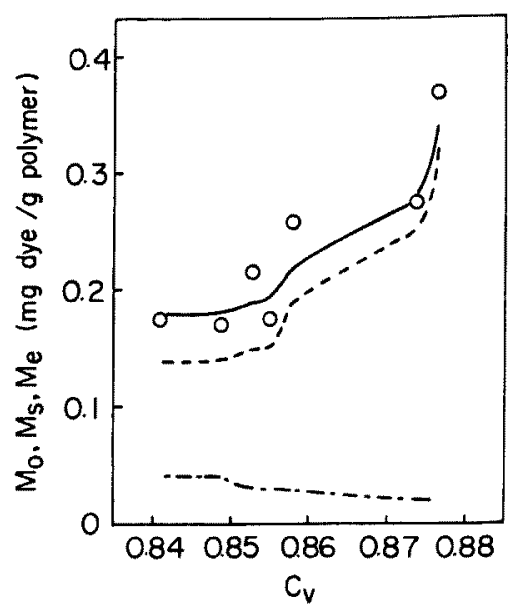

Fig. 11 Equilibrium dye uptake of PAAB vs. volume crystallinity. Open circle indicates experimental points and the solid line through these points is theoretical curve for total sorption $\left(M_{\mathrm{o}}\right)$ determined by (4). The dotted (-.-) and broken (-.-) lines are theoretical curves for the sorptions by the side region $\left(M_{s}\right)$ and by the end region $\left(M_{\mathrm{e}}\right)$, respectively.

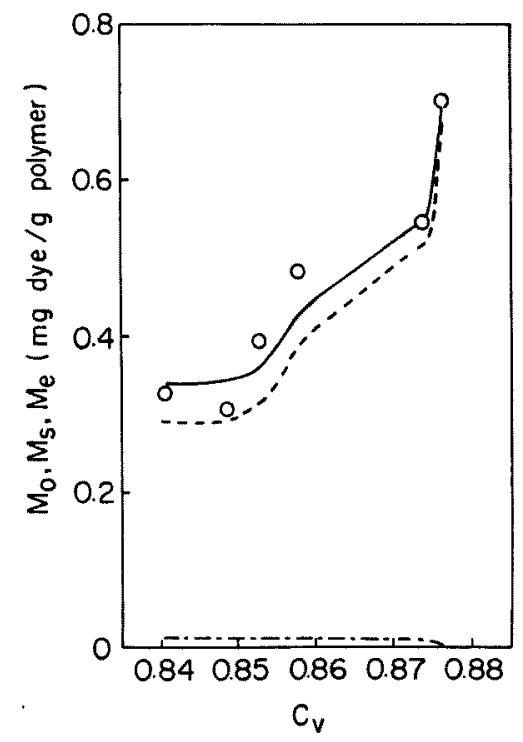

Fig. 12 Equilibrium dye uptake of Y-7 vs. volume crystallinity. The symbol and lines are the same as those of Fig. 11. 
とY-7の各々の系における $M_{9}$ と $M_{\mathrm{e}}$ の変化を示した。 両者の場合とむ $M_{\mathrm{e}}$ に比へ $M_{\mathrm{B}}$ は極めて大きい。 $C_{\mathrm{v}}$ とと もに $M_{\mathrm{s}}$ は增加するが， $M_{\mathrm{e}}$ はわずかながら減少する傾向 を示しており， $M_{0}$ はほほ $M_{\mathrm{s}}$ によって支配されている ことがわかる。 $M_{0}$ にしめる $M_{\mathrm{s}}$ の割合は，Y-7の方が

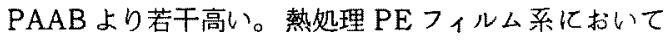
あ同様の傾向が得られて㧍り ${ }^{1)}$ ，とれはY-7 の方が PAAB上り side 領域へ染着しやすいととを示唆するす のである。以上の結果より， $M_{0}$ の增加傾向は side 領域 の染着性が向上するととに起因すると推定される。

side および end領域の非晶体皘のC $C_{v}$ 亿対する变化に ついて図 13 亿示した。 side 領域の体皘分率 $\left(V_{\mathrm{g}} / V_{\mathrm{b}}\right)$ は ほとんど変化が見られず， $C_{\mathrm{v}}=0.873$ 以上でわずが增 加する程度である。end 領域の体積分率 $\left(V_{\mathrm{e}} / V_{\mathrm{b}}\right)$ は $C_{\mathrm{v}}$ とともに減少㑯向が等められた。 $M_{\mathrm{e}}$ の変化はとの $V_{\mathrm{e}} /$ $V_{\mathrm{b}}$ の変化に対応しており， $C_{\mathrm{v}}$ の增加之ともに $M_{\mathrm{e}}$ 加隇 少するのは end 領域の体積が減少するためと考えられ る。一方， $M_{\mathrm{s}}$ の変化は $V_{\mathrm{s}} / V_{\mathrm{b}}$ の変化には対応しない。

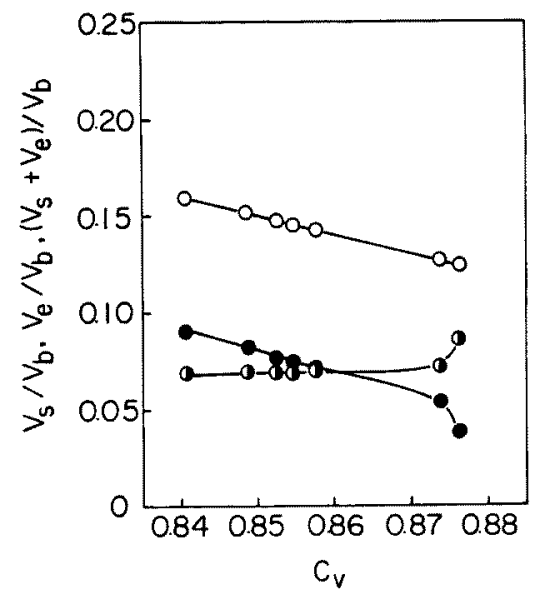

Fig. 13 Volume fractions of the side and end regions plotted against volume crystallinity. The symbols are: (O) for the volume fraction of total amorphous region $\left(V_{\mathrm{s}}+V_{\mathrm{e}}\right) / V_{\mathrm{b}} ;(O)$ for the volume fraction of side region $V_{\mathrm{s}} / V_{\mathrm{b}} ;(\bullet)$ for the volume fraction of the end region $V_{\mathrm{e}} / V_{\mathrm{b}}$.

次に， side 領域の幅であるんの変化を図 14 亿示し た。んは8〜10 ̊間の值をとっており，ほとんど変化 が認めら机ない。以上のとと加ら side 領域の染着量增 加には非晶領域の体皘以外に要因があることが示唆さ れ，それが両領域における染着性の違いを引き起とすお のと推定される。

図 15 には $C_{\mathrm{y}}$ に対する side と end 領域の染着效率の

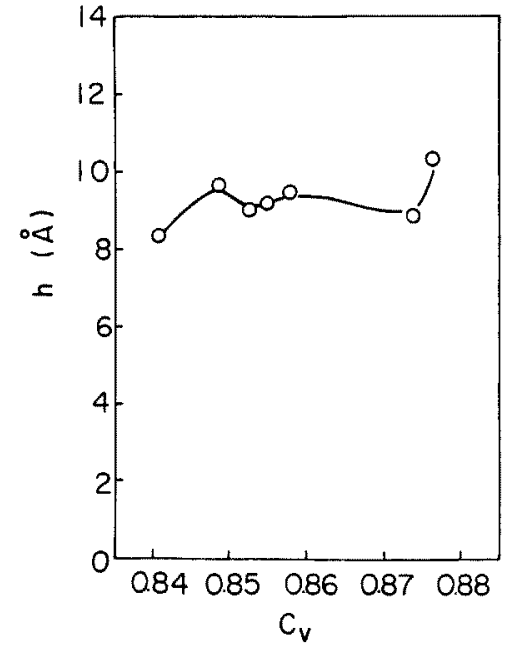

Fig. 14 The thickness of the side region as a function of volume crystallinity.

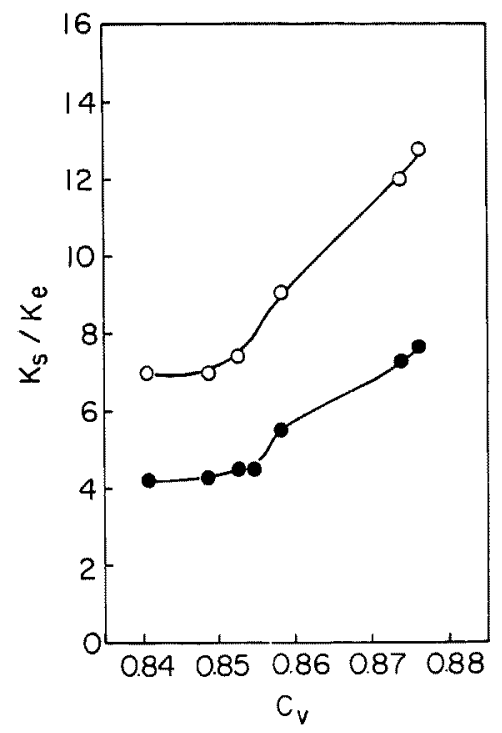

Fig. 15 Change in the ratio of $K_{\mathrm{s}} / K_{\mathrm{e}}$ for two disperse dyes as functions of volume crystallinity. Symbols indicated are as follows: (O) for Y-7; (๑) for PAAB.

比 $K_{\mathrm{s}} / K_{\mathrm{e}}$ の変化を示した。 $\mathrm{PAAB}, \mathrm{Y}-7$ 系とも，乙 の比は $C_{\mathrm{v}}$ ととむに增加する傾向がある。全温度領域に おいて，Yー7のはうがPAABより高い值を示しておう， 徉ってY-7 の方が side 領域纪染着しやすいと判断され る。更に，熱処理PEフィルム乐 ${ }^{4)}$ における $K_{\mathrm{s}} / K_{\mathrm{e}}$ の 值と比較すると両者とも PE 巣結晶マットのほうが高い 値が得られた。このような結果から PE 単結晶マットに 
おいても， $K_{\mathrm{s}}$ が染着量索增加させる重要な太子である ととが示晙された。

以上のような結果はこれまでに著者らがバルク試料に おいて得た結果 ${ }^{4 ?)}$ 乙類似している。バルク試料におい てはてれまで次のような゙推論をしてきだ。1)分散染料 のように非極性ファンデルワールスカによって，高分子 銷之物理的に結合する染料の場合には，染料は分子銷入 より接近する必要があるため，比較的伸びたコンホメー ションをとる確率の高い tie 分子加有効な染着サイトに ふり，棒状の分子形状を持つ分散染料はどこの倾问加大 きくなる。2） $C_{\mathrm{v}}$ の増加に伴う $M_{0}$ の増加はラメラの厚 化に伴い side 領域に伸びたコンホメーションをとる tie 分子の分率が増え， $M_{\mathrm{s}}$ が堌加するととに因る。

ラメラの皘層集合体である $\mathrm{PE}$ 単結晶マットにおいて， side と end領域の間の微細構造的な違いのひとつは tie 分子が end 領域にはほとんどないことである。PE䍩結 晶マットにおいて， $M_{\mathrm{s}} \subset M_{\mathrm{e}}$ の差が非常に大きく，特 に Y-7のような棒状の分散染料が end 頱域には明らか に染着しにくいという傾向が得られたというととは，上 述の推定を支持するおのである。更に， $M_{\mathrm{s}}$ が $C_{\mathrm{v}}=0.858$ を越す上急激に增加する傾向が，ラメラか厚化する傾向 とほぼ一致しているという結果は重るて上述の推論を裹 付ける事になるう。

一方， $T_{\mathrm{a}}=117^{\circ} \mathrm{C}$ 以上 $M_{\mathrm{o}}$ が急激に增加する領域は， MB 染着モデルで解析することは不可能であった。バル ク試料の Y-7 染着量よりも高くなるような領域におい ては，かなり大きな構造変化が生じていると推察され る。これは, 熱炕理に伴って単結晶全体に細孔か形成さ れる現象と関係があると思われるが，その上うな状態に 本モデルを啇用することは危險である。

\subsection{PE 单結晶マットにおける side 領域につ} いて

PE 単結晶マットにおいて，その銠結晶ラメラは図 16 に模式的に示すようにMB化していると考えられる。 また, Hosemannら”はパラクリスタル理論による解析

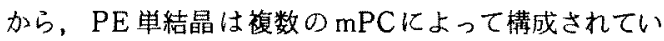
る上推論した。そこでこのパラクリスタルモデルとの対 応について検討すると，図16に示すように，1個の MBの中の微結晶コアがmPCに相当し, end 領域はラ メラの fold 部分に, side 領域は $\mathrm{mPC}$ 間の境界に対応 すると考えられる。この境界はらせん転位による twist boundaryであり，格子准であると考えられている”。 MB 染着モデルによる解析結果加ら得られた side 領域

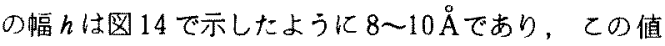
は(110)面の面間隔である $4.114 \AA$ 吕約 2 倍に相当して いる。との side 領域が格子久陷部であるとすれば，こ

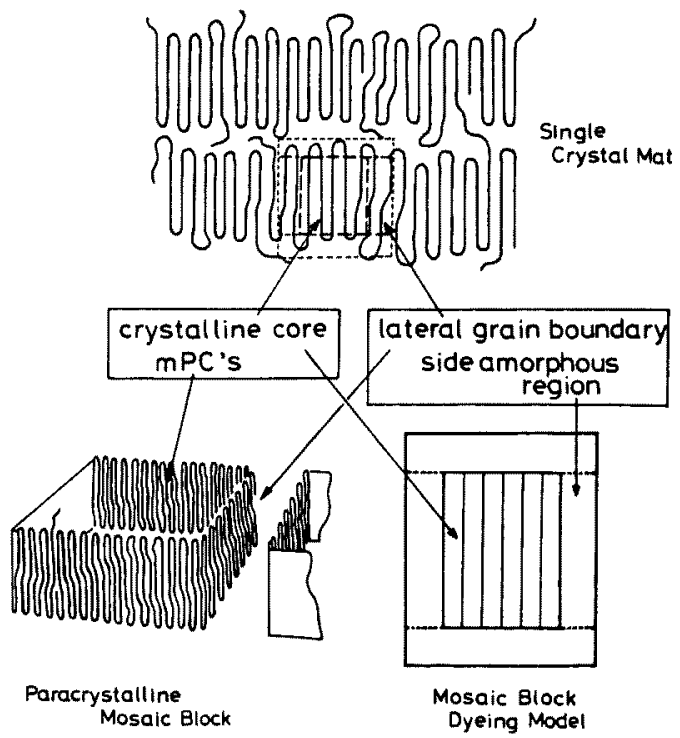

Fig. 16 The schematic representations of mosaic block dyeing model and paracrystalline model. ${ }^{1)}$

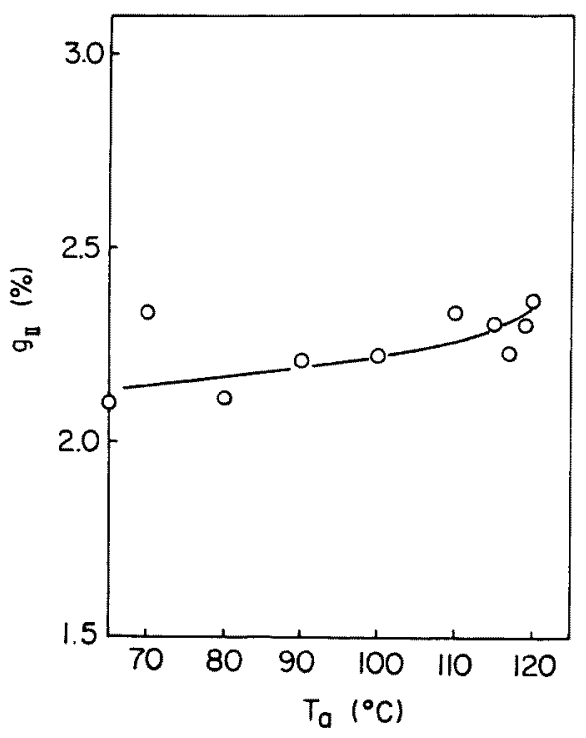

Fig. 17 Change in $g_{\mathbb{I I}}$ as a function of annealing temperatures.

の領域に存在する非晶分子鎖は比較的伸びた trans タイ プのコンホメーションをとっていることは想像に難くな い。即ち，Y-7のような棒状の分散染料が吸着しやす い分子形態をとっていると判断できる。

又，PE単結晶を熱処理すると格子尔陌が增加すると 
とが，てれまでにSlichter ${ }^{16)}$ の NMR, Holland ${ }^{17)}$ の アレ図形の研究などにより明らかにされている。本研究

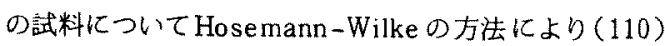
面の面間隔のゆらぎ $g_{\text {II }}$ 求めた結果，図 17 亿示すよう に， $g_{\text {II }}$ は熱处理温度の上昇と共にわずかに增加する傾 向が認められる。とのととより熱処理温度が高くなると ラメラの(110)面に垂直方向の結晶格子の乱れが大きく なるととが示唆される。微結晶の乱れの大きい試料では 染料分子が side 領域に吸着する確率が高くなり，染着 量が增加するものと推定される。

\section{4. 結論}

（1） PE 単結晶マット一分散染料系においてもMB染 着モデルの適用が可能であり, side 領域の染着量が end 領域に比べて著しく大きいととが明らかになった。その 差は $Y-7$ のうな棒状の形態をとる染料分子ほど大き くなる傾向がある。

(2) PE 単結晶マットの end 領域には tie 分子がほ上 んど存在しないと考えられるととから, side と end 領域 の間の染着性の差は，比較的伸びたコンホメーションを とり得て、Y-7のような染料分子が接近しやすいと予 測される tie 分子に起团すると推察される。

(3) MB染着モデルに抽るるside 領域は,パラクリ スタルモデルに拈りる $\mathrm{mPC}$ 間境界と対応づけることが 可能であり，その境界に存在すると考えられる比較的伸 びたコンホメーションをとる PE 分子鎖に棒状の分散染 料分子が吸着しやすい之推定される。

（4）䊅晶化度の增加化伴う平衡染着量の増加は, ラメ ラの厚化および微結晶の乱れにより side 領域に伸びた コンホメーションをとる非晶分子銷の分率が增加すると とに起因する上考元らる。

以上の結果はこれまでのバルクポリマーにおける推論 を支持するものである。

付 記：本研究を進めるにあたり御協力をいただいた 山形大学工学部技官井上みよ子, 佐々木一男両氏に感謝 します。本研究は縤維学会昭和 59 年度年次大会研究発
表会(昭和 59 年 5 月 12 日, 東京)で発表した。

\section{文献}

1) R. Hosemann, W. Wilke and F.J. Baltá Calleja, Acta Crystallogr., Sect. A, 21, 118 (1966)

2) M. Takayanagi and T. Matsuo, J. Macromol. Sci., Phys., B1 (3), 407 (1976)

3) 山田憲二，高柳素夫，高分子論文集， $32 ， 724$ (1975)

4) T. Masuko, S. Hasegawa, K. Yonetake and M. Karasawa, Makromol. Chem., 182, 2049 (1981)

5) K. Yonetake, T. Masuko, T. Simanuki and M. Karasawa, J. Appl. Polym. Sci., 28, 3049 (1983)

6) K. Yonetake, T. Masuko, K. Takahasi and M. Karasawa, SEN-I GAKKAISHI, 40, 294 (1984)

7) K. Yonetake, K. Nagamatuya and T. Masuko, to appear in J. Appl. Polym. Sci.

8) E. W. Fischer, R. Lorenz, Kolloid-Z.Z. Polym., 189, 97 (1963)

9) Dannusso, G. Moraglio, W. Ghiglia, L. Motta and G. Talamini, Chim. Ind. (Milan), 41, 748 (1959)

10) H. P. Klug and L. E. Alexander, "X-ray Diffraction Procedures", 2nd Ed., Wiley, New York 1974, Chap. 9, p. 656

11) F. Hamada, B. Wunderlich, T. Sumida, S. Hayashi and A. Nakajima, J. Phys. Chem., 72, 178 (1968)

12) W. O. Statton and P. H. Geil, J. Appl. Polym. Sci., 3, 357 (1960)

13) E. W. Fischer and G. F. Schmidt, Angew. Chem., 74, 551 (1962)

14) T. Masuko, M. Sato and M. Karasawa, J. Appl. Polym. Sci., 22, 1431 (1978)

15) A. Keller, Polymer, 3, 393 (1962)

16) W. P. Slichter, J. Appl. Phys., 31, 1865 (1960)

17) V. F. Holland, J. Appl. Phys., 35, 3235 (1964) 